\title{
Marko Uršič
}

\section{O spominu in celovitosti duše}

\begin{abstract}
Ključne besede: spomin, anámnesis, preseljevanje duš, kvazispomini, digitalni spomin, Platon, Aristotel, Ciceron, Plotin, Dante, François-René de Chateaubriand, Parfit, Marcel Proust
\end{abstract}

\section{DOI: 10.4312/ars.12.2.19-40}

Včasih pomislim, da pravzaprav že vse življenje pišem o spominu, še več, v nekem širšem ali globljem pomenu pišem samo o spominu. Osrednja tema mojega literarnega prvenca, romana Razpoke (1985), je bil ravno spomin, natančneje, spominjanje ali »zbiranje« lastne preteklosti glavnega junaka Jona, ki mu je bila zaradi nekih, recimo, »fantastičnih « okoliščin večji del zastrta, vendar ne povsem - in ravno v tem »ne povsem « je ne le Jonova, temveč nasploh naša človeška spominska bolečina, nenehno hrepenenje zaradi razpok v celovitosti duše, obenem pa tudi upanje, da jo je mogoče (znova) zbrati z vztrajnim in vsakdanjo danost presegajočim spominjanjem. Roman se začne takole: »Včasih se je Jonu zazdelo, da se je spomnil svojih prejšnjih življenj, a spomin je bil preveč zastrt s pajčolanom videza, da bi v njem našel odrešujočo resnico« (Uršič, 1985, 7). Takrat sem se navduševal za vzhodno modrost, ki jo seveda tudi dandanes zelo spoštujem, vendar do nje nimam več tako »bližnjega« (tj. lahkotnega) odnosa kot v mlajših letih, dvignila se je nekam "visoko nad mene«. V mladosti so me pritegnile zlasti budistične sutre in upanišadske modrosti, za moto v svojem prvem romanu pa sem izbral štiri verze iz Bhagavadgite, ki jih izreče bog Krišna mlademu Arjuni: »Mnogokrat sem bil rojen, o Arjuna, / in mnogokrat si bil rojen ti - / a jaz se spominjam preteklih življenj, / pozabil si ti tiste dni« (prevod je /bil/ moj, iz angleščine). Spomin je gotovo nekaj božanskega ...

In ko zdaj, tri leta pred svojimi sedmimi križi, gledam nazaj v lastno in obenem našo skupno preteklost (saj nikoli nista povsem ločeni), ugotavljam, da moja "pretekla življenja« niso (bila) le tista pred mojim rojstvom - o njih ne vem nič več kot mladi Arjuna, razen morda to, da so (bila) moja pretekla življenja v resnici življenja drugih, mnogih duš, tudi tistih, ki so zapustile ta svet davno pred mojim rojstvom -, ampak da sem že v tem svojem ne ravno kratkem življenju (v svoji »kratki večnosti«, kot je lepo dejal naš pesniški starosta Ciril Zlobec) živel več življenj. Koliko življenj sem že preživel v tem svojem edinem življenju, je odvisno predvsem od tega, katere mejnike med njimi izberem. Lahko bi rekel, da sem doslej živel skupaj s sedanjim že najmanj 
tri življenja, nekako tako, kot pravi Emily Dickinson v svoji znameniti pesmi (№ 1732): My life closed twice before its close ... (»Moje življenje se je sklenilo dvakrat, preden se bo sklenilo«) -, lahko pa tudi rečem, da sem živel že na tisoče življenj: vanje se prebujam ob vsakem novem jutru.

Takrat, ko so izšle moje mladostne Razpoke, je bilo moje "prvo življenje« že vrsto let za menoj. Sklenilo se mi je namreč nekje ob koncu študentskih let, kronološko sredi sedemdesetih. Moje dolgotrajno in večkrat predelano ubesedovanje Jonove romaneskne zgodbe, njegovega spominskega iskanja izgubljene celovitosti duše, pa je bilo seveda vsaj deloma avtobiografsko, četudi preneseno iz Ljubljane v kvazirealnost fantastičnega velemesta, v katerem elektronski spomini prevladujejo - že takrat! - nad človeškimi. Miselno in tudi čustveno izhodišče tega romana o spominu in pozabi je bilo vprašanje, ki me je preganjalo ob koncu mojega "prvega življenja« in ga lahko povzamem, če poenostavim, takole: Ali bom v svojem drugem, tj. naslednjem življenju, $\mathrm{v}$ katerega nujno in nepreklicno vstopam, zmogel ohraniti celovitost mojega (dotedanjega) življenja? Ali, malce bolj filozofsko rečeno: Ali bom ohranil »hipostatično« enost mene-samega, moje duše, globljega »sebstva«, ki naj bi kljub vsem premenam segalo prek mojih posameznih življenj? Če bi se vnaprej sprijaznil $\mathrm{z}$ dejstvom - ne le sprijaznil, temveč ga sprejel z mistično radostjo -, da tisto pravo, najvišje Sebstvo ni nič drugega kot praznina (seveda v vzvišenem pomenu, recimo kot indijska śūnyatā), potem se ne bi spraševal tako, kot sem se ob prehodu iz svojega prvega $\mathrm{v}$ drugo življenje (in pozneje, iz drugega $\mathrm{v}$ tretje ...). Toda tisto moje »slovo od mladosti« - kajti za to je pravzaprav šlo, čeprav precej drugače kot pri Prešernu - je bilo nostalgično in boleče ravno zato, ker sem bil prepričan (in sem še vedno), da je bilo v prvem življenju tolikanj lepega, zlasti pa resničnega, da ga moram ohraniti v živem spominu, če hočem obdržati svojo celovitost, svojo dušo. Pozneje, ko se nam na nekem drugem in drugačnem življenjskem "prelomu « ponovi slovo od lastne preteklosti, je duša nanj že bolj pripravljena, četudi bolečina slovesa in upanje v novo življenje nista nič manjša kot prvič. (Gotovo pa se ju ne dá meriti z vatlom.) Moji duši je bilo doslej prihranjeno občutje tiste popolne življenjske praznine - in upam, da mi bo tudi $\mathrm{v}$ prihodnje -, ki ga je naš pesnik ubesedil v svojih pretresljivih, genialno preprostih verzih: »Sem dolgo upal in se bal, / slovo sem upu, strahu dal; / srce je prazno, srečno ni, / nazaj si up in strah želi.«

Torej, ali je mogoče v spominu ohraniti celovitost duše pri prehajanju skozi več zaporednih (v mnogoterem času tudi vzporednih) življenj? Česa iz naših prejšnjih življenj naj se spominjamo in kaj naj (rajši) pozabimo? Seveda se lahko vprašamo tudi drugače, "psihoanalitično«: česa se sploh lahko (sami) spomnimo - in česa se ne moremo? Katera svoja doživetja, zlasti iz otroških let, smo nezavedno "potlačili« v pozabo - in zakaj? Vsekakor so to zanimiva in za človekov dušni blagor zelo relevantna 
vprašanja, na katera je mogoče odgovoriti na več načinov (vsaj na dva, sledeč Freudovi ali Jungovi varianti psihoanalize), vendar v tem eseju ni moj namen razpravljati o travmah in doživetjih iz otroštva ter njihovem vplivu na poznejše življenje, še manj pa o odnosu med zavestjo in nezavednim nasploh, saj se o tem pri nas dovolj, že skoraj preveč piše. Rajši bom premišljeval o zavestnih spominih, tj. takšnih, ki niso (bili) "potlačeni« v nezavedno oziroma v "podzavest « zaradi kakih travmatskih vsebin, ampak preprosto bledijo s časom, ker jih naravni red sveta prekriva $\mathrm{z}$ vsakim novim trenutkom, tako kot valovi brišejo stopinje na peščeni obali. Kajti čeprav se zavedam, da je v mojem življenju marsikaj odvisno od mojih doživetij v najzgodnejših, otroških letih, sem o celovitosti svoje duše in o spominu kot ohranjanju te celovitosti začel razmišljati šele kot mladenič, na pragu zrelosti, in to vprašanje je doseglo (prvi) vrh ravno ob "slovesu od mladosti«, ob prehodu iz prvega v drugo življenje. Tisto, česar se zavedam, je - vsaj deloma - »v moji moči«, namreč da skušam vse, kar sem doživel in česar ne bi rad pozabil, ohraniti in sčasoma morda tudi »sublimirati« v samem sebi, seveda ne da bi pri tem kakorkoli spreminjal ali celo "povzročal« svojo lastno preteklost v pomenu, kakor o tej možnosti razpravljajo nekateri filozofi (med modernimi zlasti Dummett, 1978, 319-374). Sam spominjanje dojemam v smislu platonske anámnesis, tj. kot eminentno možnost sámospoznanja in sámoočiščenja duše.

$\mathrm{V}$ tem hotenju pa vselej ostaja mnogo nerazrešenih aporij. Ena izmed njih je že osnovno vprašanje, zakaj naj bi človek sploh stremel k celovitosti in/ali enosti svoje duše, svojega življenja? Je to hotenje sploh smiselno, je vredno truda? In navsezadnje, zakaj je sploh dobro karkoli ohraniti? Mar ni bolje, da se, zlasti na koncu poti, prav vse »izbriše«, da ostane samo tista vsepresežna, čista in "prazna«, slepeče sijoča in obenem ljubeče blaga svetloba - ali pa brezdanja temà, saj sta »tam « morda obe eno in isto? Ali pa, še bolj pesniško povedano, da ostane samo "neskončna modrina«, tako kot v Kosovelovi pesmi $O$, saj ni smrti: brezdanja modrina, v katero "padaš, padaš, padaš« in v njej »sam postajaš, sam in neviden« ... Pesniki in vidci vejo, da je tako. Jaz pa, vselej iščoči filozof, zdaj ko na sredi »življenja póta (kronološko sem že krepko čez) tuhtam o vesoljni dilemi vse ali nič (ali, še rajši, ko premišljujem o »tretji možnosti«: vse in nič), spet prehitevam svoj čas. Saj sem še »tu«, četudi me nemirna duša vedno znova opominja, naj ne pozabim na tisto svetlobo (ali temo) »tam«.

Kakorkoli že, dokler sem »tu«, si prizadevam skozi vsa svoja tostranska življenja ohraniti v spominu (za "večnost«?) prav ta trenutek - in najbrž bom želel ohraniti tudi lepoto svojega "poslednjega trenutka«, tako kot Faust, četudi ne bom vedel, da je poslednji. Trenutke svojih mnogih življenj skušam ohranjati na različne načine, ne nazadnje tudi s temi besedami, ki jih prav zdaj pišem, in s številnimi spominskimi oporami, recimo s fotografiranjem krajev, po katerih hodim skozi svoj neskončnokončen čas. Ko sem bil pred tremi leti na Islandiji, sem v dvanajstih dneh potovanja 
po čudovitih in osupljivih pokrajinah tega otoka posnel okrog tisoč dvesto fotografij, pa še nekaj filmčkov za povrh. Seveda sem se post festum spraševal, zakaj oziroma čemu to počnem. Gotovo je eden izmed pomembnih razlogov fotografiranja v tem, da lahko lepoto dežele, ki smo jo obiskali, doma pokažemo svojim bližnjim. V ta namen sem izbral kakih tristo slik, ki sem jih na računalniku nekoliko obrezal in ponekod tudi malce drugače, bolj "narativno«, razvrstil. Toda če bolje premislim, prikazovanje moje poti drugim vendarle ni bil glavni razlog tega že kar preveč ekstenzivnega fotografiranja. Ob projekcijah mi je postajalo vse bolj jasno, da mi ta dolga serija posnetkov omogoča predvsem to, da jo kakega samotnega večera spet »zavrtim« samemu sebi in se tako znova »umestim« v tisti pretekli, minuli prostor-čas. $\mathrm{S}$ pregledovanjem fotografij se spomnim samega sebe na Islandiji, omogočajo mi, da $\mathrm{v}$ spominu podoživim in v svoji živi sedanjosti »razčasim« razdaljo med tistimi »kraji« (v gr. pomenu toposi) daleč na severu, pred tremi leti - in menoj, ki sem zase vselej tu, vendar sem ta trenutek fizično daleč od tam. V ta namen pa je boljše kot že filtrirani izbor pregledati celoten niz še neobdelanih fotografij (ali vsaj, če ni na razpolago dovolj časa, vse "po obrokih", recimo vse posnetke nekega dneva). Za ponovno umestitev samega sebe $\mathrm{v}$ daljne/minule topose je namreč pomembna čim bolj natančna časovna razvrstitev fotografij, saj tako ob reprodukciji poleg spominov na tiste krajine lažje podoživiš tudi lastne korake in nasploh svoje premike v njej, tj. "poustvariš« si celoten prostor-čas dogajanja, čeprav ni v celoti viden na nobenem posameznem posnetku (tudi za film velja podobno, namreč za zaporedje posameznih sekvenc) - in s tem dosežeš tisto, kar je za občutek resničnosti spominov najvažnejše: v sedanjem času, tu-in-zdaj, »ponoviš« sebe v tistem daljnem prostoru.

Nekaj podobnega bi lahko rekli za pisanje dnevnikov, za zapise sanj, posebno pomembnih doživetij ipd. Upam, da ne bom prehitro preskočil iz profanega $\mathrm{v}$ sakralno, če že na tem mestu povem, da lahko med tovrstne spominske vzgibe duše uvrstimo tudi znameniti Pascalov »Spominek“ (Mémorial), njegov kratek zapis religiozno-mističnega videnja Boga v noči 23. novembra 1654. Pascal je svoje ognjeno razsvetljenje zabeležil na pergament, ki ga je všil pod podlogo svojega površnika, kjer ga je hranil osem let, vse do svoje smrti - da ne bi pozabil tistega, česar ni mogoče pozabiti (gl. Pascal, 1980, 187-88). Ob tem Pascalovem najvišjem razodetju Ognja, $\mathrm{v}$ katerem zgorijo vse stvari tega sveta, se mi znova, še posebej ostro in neizprosno zastavlja vprašanje, čemu skušamo ohraniti ves svoj svetni »ništrc«, na katerega smo "tu « navezani, ker nas razveseljuje in nam daje voljo do življenja. Kaj od vsega tega, kar želimo ohraniti, recimo s "posedanjenimi« slikami z Islandije, bomo lahko nesli »tja čez«? Morda ničesar. Morda vse. Mistiki nas učijo, da je »vse odveč«, ali drugače rečeno: da se "tam«, kjer je vse prisotno, ni treba prav ničesar spominjati. Morda res, vendar jaz, namreč moj drobni svetni jaz, zdaj še nisem »tam« in včasih celo 
podvomim, ali tista »vsepresežna vseprisotnost « sploh je (kje je in kdaj, je vselej in/ ali nikoli?).

Na pragu mojega »tretjega življenjskega obdobja «, ki bo kronološko nastopilo dober teden dni po pisanju tega eseja, se kot filozof vedno znova sprašujem, kaj je sub specie aeternitatis bolje, bolj resnično: Vse ohraniti ali Vse izbrisati? Kolikor je ta dilema sploh nujna, zagotovo pa je bolj božja kot človeška. Morda pa tudi peklenska. Kajti enako vprašanje kot glede osebnih spominov se nam zastavlja tudi v odnosu do našega skupnega zgodovinskega spomina. William Blake je v Poroki nebes in pekla zapisal: »Bil sem v tiskarski hiši v Peklu in opazoval način, s katerim je znanje posredovano od rodu do rodu. / V prvem prostoru je bil Zmaj-človek, ki je odstranjeval smeti izpred jamskega vhoda [...] V petem prostoru so bile Brezimne oblike, ki so metale kovine v prostranost. / Tu so jih prejemali Ljudje, ki so zasedali šesti prostor in dobili oblike knjig, ki so jih zlagali v knjižnicah«(Blake, 1972, 16). V nekem drugem »dragocenem videnju « pa nam Blake pričuje: »Po večerji sem vprašal, ali bi Izaija lahko počastil svet s svojimi izgubljenimi deli; rekel je, da ni bilo izgubljenega nič vrednejšega. Ezekiel je podobno rekel za svoje delo« (ibid., 15). - Vselej novi rodovi, ki »stojimo na ramenih velikanov«, se oziramo nazaj k njim in se spominjamo, kaj so ti velikani mislili, videli in občutili, da bi se zmogli mi sami boriti z minevanjem časa, kaosom in smrtjo. $\mathrm{V}$ nadaljevanju se bom s svojim človeško luknjičavim spominom, ki mu, hvala bogu, pomagajo knjige, na kratko ustavil pri nekaterih izmed teh velikanov, ki jih občutim kot svoje starejše brate $v$ duhu, sebe pa kot njihovega prav majhnega bratca. Poskušam jih razumeti in jih v sebi znova obuditi v življenje, dokler in kolikor zmorem. Kajti »oživiti« vélike duhove preteklosti ne pomeni zgolj ponavljati njihove besede in spoznanja, temveč premisliti, kako njihove misli odzvanjajo $v$ meni samem.

Prvi del tega eseja o spominu in celovitosti duše, ki očitno ni in tudi v nadaljevanju ne bo kak teoretsko-akademski traktat (ob vsem spoštovanju do slednjih), saj ga pletem tudi iz dokaj osebno obarvanih níti, bom končal z nič manj osebno obarvanimi Chateaubriandovimi besedami iz njegove slavne knjige Spomini onkraj groba, tj. iz življenjskega dnevnika, ki je bil, kot je sam zapisal, njegovo najljubše delo. Takole pravi v predgovoru: »Te Spomine sem sestavljal ob različnih dnevih in v različnih deželah. [...] Moja mladost, ki prenika $v$ mojo starost, izkušenost zrelih let, ki prinaša otožnost $\mathrm{v}$ moja nora leta, žarki mojega sonca, ki se od zore do mraka križajo in prepletajo, so vnesli v moje pripovedi nekakšno zmedo, ali, če hočete, nekakšno neopredeljivo enotnost; moja zibel je podobna mojemu grobu in moj grob moji zibeli; moje trpljenje se sprevrača v veselje, moje radosti v bolečine in ko sem $\mathrm{z}$ branjem svojih Spominov na koncu, ne vem več, ali so izšli iz temnolase ali osivele glave« (Chateaubriand, 1989, 6). 
Prvi velikani, o katerih želim v tem eseju o spominu zapisati nekaj besed, so stari egipčanski faraoni. Mnogo jih je bilo, v številnih dinastijah, v več tisočletjih te veličastne kulture, za katero se nam zdi, da je vzniknila tako rekoč »iz nič«. V Starem kraljestvu najbolj izstopa vélika trojica faraonov četrte dinastije: Keops (Kufu), Kefren (Kafra) in Mikerin (Menkaure). V spominsko večnost so se zapisali s tremi največjimi piramidami, ki jih »varuje« velika Sfinga. O tem, kdo so bili ti trije faraoni za življenja, kakšna so bila njihova človeška obličja, značaji in navade, kako so vladali in nasploh živeli, vemo bolj malo, pa še to pretežno iz mnogo poznejših, historično nezanesljivih virov. Herodot je do Keopsa in Kefrena zelo neprizanesljiv, češ da sta bila kruta vladarja, medtem ko hvali najmlajšega med njimi, Mikerina (gl. Herodot 1953, I/201206 [II.124-135]). Kljub temu pa ta trojica še po štirih tisočletjih in pol »živi« med nami, njihova imena spominsko niso obledela tako kot njihovi človeški obrazi in lahko bi rekli, da so sáme piramide njihove posmrtne simbolne »inkarnacije«. Ernst Cassirer v Mitičnem mišljenju (1928), drugi knjigi Filozofije simbolnih form, piše o geometrijski, »arhitekturni formi stvari« v egipčanski umetnosti in med drugim ugotavlja: »V svoji jasnosti, stvarnosti in večnosti ta forma triumfira nad vsako preprosto sukcesijo, nad nenehnim tokom in minljivostjo vseh časovnih konfiguracij. Egipčanska piramida je vidno znamenje tega zmagoslavja, zato je simbol temeljne estetske in religiozne intuicije egipčanske kulture [... kajti] za mit smrt ni nikoli izničenje bivanja, marveč zgolj prehod v drugo vrsto bivanja« (Cassirer, 1955, II, 128). Piramida kot geometrijska forma je s svojo poudarjeno vertikalo in kvadratno »uzemljitvijo« izraz človeškega hrepenenja po presežnem, in ravno s to svojo čisto obliko, utelešeno $\mathrm{v}$ kamnu, so tri piramide $\mathrm{v}$ Gizi, kot sem že dejal, posmrtne »inkarnacije« treh velikih faraonov. Zanimivo pa je, da tudi pri poznejših dinastijah, ki so zgodovinsko bolje dokumentirane, pogosto več kot o življenju samih faraonov vemo o kakem dvornem dostojanstveniku ali celo o članih umetniških in rokodelskih skupin (npr. iz arheoloških najdb v nekdanji »cehovski« vasici pri starih Tebah, na kraju, ki se danes imenuje Deir el-Medina). Glavni razlog za to nesorazmerje je bržkone $\mathrm{v}$ tem, da so bile faraonske grobnice večinoma izropane, mnoge že $\mathrm{v}$ antičnem času. (Seveda so tudi srečne izjeme, npr. Tutankamonova grobnica, pa arheološka pričevanja o Ehnatonu ipd.)

Za naše razmišljanje o zgodovinskem spominu na posamezne osebnosti je še posebej zgovorna primerjava faraona Mentuhotepa II. Nebhepetre iz 11. dinastije - zmagovitega vojskovodje, ki je vladal več kot šestdeset let v 21. st. pr. n. š. ter z združitvijo Zgornjega in Dolnjega Egipta znova vzpostavil enotno državo (Srednje kraljestvo) - in njegovega dvorjana, "čuvarja zaklada« (danes bi rekli premiera) z imenom Meket-Ra (»Sonce je moja zaščita«). O faraonu, ki si je postavil mogočen posmrtni tempelj v (današnji) Deir el-Bahri, blizu poznejšega in bolj znanega svetišča kraljice Hačepsut, je razen o njegovih zmagoslavnih pohodih in velikih stavbarskih 
delih znano bore malo, namreč o njegovem življenju, o njem kot nekoč živi osebi medtem ko si je njegov dvorjan Meket-Ra tako rekoč nehote (ali vsaj nevede), seveda pa tudi s pomočjo naklonjene mu usode, dal izdelati triindvajset pobarvanih lesenih modelov v velikosti otroških igrač, célo zbirko verističnih »replik «, pomanjšanih kopij svojega imetja, hiše in vrta, hlevov z živino in drobnico, delavnic, pa figurice služinčadi, pisarjev in stražarjev, lovcev in pastirjev, ribičev in veslačev, ki naj bi po Meket-Rajevi smrti služili njegovemu kaju (onstranskemu »dvojniku«); med vsemi temi njegovimi posmrtnimi »igračami« pa je najbolj presenetljiva in presunljiva flotilja sedmih bark s celotnimi posadkami in opremo: sprevod pomanjšanih plovil, s katerimi je - seveda $\mathrm{z}$ »originali« - za časa zemeljskega življenja kot bogat trgovec prevažal svoje blago po Nilu, po njegovi smrti pa so te barke ponesle njegov khat (mumijo), skupaj z vsemi modelčki, v grobnico na zahodnem bregu Vélike reke. Meket-Ra je bil pozabljen skoraj štiri tisočletja, vse do pomladi 1920, ko so arheologi odkrili njegovo grobnico in za roparje nevredne predmete v njej, večino jih lahko vidimo v Metropolitanskem muzeju v New Yorku (več o Meket-Rajevi zgodbi gl. Uršič, 2015, 42 isl.).

Drugi niz velikanov, na ramena katerih se bom za nekaj trenutkov zavihtel v tem eseju, so homerski junaki in bogovi v Iliadi in Odiseji. Kdo bi dandanes (pa tudi že v klasični grški dobi) še vedel za slavne in pretresljive zgodbe arhaičnih junakov Ahila, Hektorja, Patrokla, Helene, Andromahe, Kasandre in vseh drugih vélikih grških likov, med njimi seveda tudi Odiseja na njegovi dolgi poti domov na Itako, ko ne bi bilo Homerja oziroma njegovih (in/ali poznejših) nesmrtnih stihov, ki opevajo te mitične dogodke, ljudi in bogove? Še več, ali bi bili grški bogovi takšni, kot jih poznamo (in kakršne je poznal že Sokrat), če ne bi bilo Homerja? Najbrž bi bili drugačni, morda Atena ne bi bila tako pametna, niti Hera bolestno ljubosumna, niti ne bi bil sèl bogov Hermes naklonjen ljudem; pa tudi za čarovnico Kirko ne bi vedeli (kaj šele za nesrečnega Elpenorja, ki tam pri njej pade s strehe), niti za enookega velikana Polifema, niti za prelestno nimfo Kalipso, če nam jih ne bi verzi ohranili v spominu. O, kako revnejši bi bil ne samo grški, ampak tudi naš današnji svet brez Homerja, brez njegovih spominov na čase in kraje, ki morda sploh nikoli niso obstajali, skoraj zagotovo pa ne v takšni obliki, kot jih je ovekovečil v svojih heksametrih! - Tudi sami bogovi so očitno imeli spomin, sicer ne bi mogli posegati v človeški svet (čeprav so pogosto povzročili več zmede kot reda), medtem ko tega ne moremo reči za mrtve duše v Hadu, ki jih le za nekaj trenutkov znova oživi žrtvena kri, ki jo Odisej ob prihodu v podzemlje izlije nanje (gl. Odiseja, 11, 34-40).

Povsem drugače so onstranski spomin dojemali orfiki, o čemer smo poučeni iz njihovih zlatih lističev v grobovih. Kot ugotavlja Mircea Eliade, se je vloga pozabe in spomina, reke Léte in jezera (ali studenca) Mnemosýne, pri orfikih obrnila glede na homersko izročilo: »Pozaba ne simbolizira več smrti, ampak vrnitev v 
[tostransko] življenje« (Eliade, 1996, II/119). In ko duša zapusti to življenje, znova pride $\mathrm{v}$ onstransko pokrajino, ki pa je sprva ne prepozna, v njej se ne znajde, zato potrebuje kažipote: »V Hada domovih na levi boš našel izvir, / ob katerem stoji bela cipresa [...] Reci jim [stražarjem]: 'Zemlje otrok sem in zvezdnega Neba, / toda rod moj je nebeški. To sami že veste. / Od žeje sem izsušena in propadam! Dajte mi brž hladne vode, ki iz jezera Spomina priteka' " (Fragmenti predsokratikov, 2012, I/31, DK 1 B 17). - Ko beremo, vedno znova, fragmente predsokratikov, te dragulje z daljnobližnjih obal naših začetkov, lahko ugotavljamo, da so med njimi orfiki s svojo skrbjo za spomin pravzaprav izjema. Za večino teh starih modrecev bi lahko rekli, da jih je bolj kot spomin zanimalo premišljevanje o prisotnosti, neskritosti (alétheia) bivanja. To ne velja le za Parmenida, ampak tudi za Heraklita in »hilozoiste«. Svet je bil takrat še mlad. V primerjavi s predsokratskimi mislimi pa so Platonove že »starejše» (čeprav so historično mlajše): »božanski Platon« je glede spominjanja (anámnesis) na večno življenje »tam«, onstran, sledil orfikom, vendar je s svojim umskim videnjem idejnega sveta, zlasti pa svetlobe Dobrega, ki preseva ves svet ter povezuje tostranstvo z onstranstvom ( $c f$. prispodobo o votlini), ne samo poglobil, temveč tudi filozofsko preoblikoval orfiške nauke o eshatologiji spomina. Sicer pa so to znane, vselej žive klasične misli ...

Plotin, ta véliki filozof-mistik, ki je »povzel« in seveda tudi nadalje razvil tisočletno duhovno bogastvo antične filozofije, je med svojimi 54 traktati najdaljšega namenil premišljevanju o duši. V tridelnem traktatu Aporije o duši (En. IV 3-5), v sklopu obširne in razvejane tematike o vrstah duš, duševnih zmožnostih, odnosu med dušo in umom itd., ki jo razvija v 85 poglavjih tega traktata, posebno pozornost (v 13 poglavjih) posveča prav spominu. Ker pa $\mathrm{v}$ pričujočem zborniku o tej temi podrobneje piše kolegica dr. Sonja Weiss in ker tudi sam razpravljam o spominu pri Plotinu v uvodni študiji k drugemu zvezku slovenskega prevoda njegovih Zbranih spisov (2018), se bom tu za hip ustavil samo pri nekem detajlu, ki se mi zdi ne le filozofsko oziroma teoretsko zanimiv, ampak tudi človeško pretresljiv. Plotin v skladu s svojo filozofsko mistiko presežnega Enega, izraženo tudi v eni izmed njegovih ključnih maksim: »Odpovej se vsemu!« (áphele pánta, dob. »Odstrani vse!«, En. V. 3[49].17.39), v razpravi Aporije $o$ duši pravi, da »spomin - četudi se duša spominja najboljšega [tj. Uma, Enega] sam ni nekaj najboljšega« (En. IV[28].4.5.7), kajti višja od spomina je prisotnost (parousía) tistega, česar nočemo in tudi ne moremo pozabiti/izgubiti. Zato bogovi (ali tiste božanske duše, ki živijo v Umu) nimajo potrebe, da bi se česa spominjali, saj jim je vedno, brezčasno vse prisotno. Toda ko se že zdi, da je človeška duša razrešila uganko spomina, se vanjo vrne dvom: »Kako pa je s spominom na prijatelje, otroke, ženo? Ali pa na domovino in na vse tisto, česar naj bi se upravičeno spominjal vsak spoštovanja vreden človek? «(En. IV 3[27].32.1-2). Le kako naj vse to pozabimo? (Bi 
bil Dante lahko srečen v raju, če v svoji onstranski vodníci ne bi prepoznal Beatrice?) Plotinov odgovor se navezuje na stoiško ataraksijo: »[Nižji] del duše se vsake od teh stvari spominja z občutji; a tak [višji] človek se jih lahko spominja tudi, ne da bi ob tem kaj občutil« (ibid., 31.1-3). Ampak kaj, ko je ravno občutje bistven del spomina nanje! In tako tudi ta aporija duše ostaja nerazrešena ...

Ko sem že pri Danteju, lahko rečem, da je celotna Božanska komedija gigantski napor spomina, da bi zaobjel vsa tri onstranska kraljestva, pekel, vice in nebesa. Od kod naj bi pesnik črpal vse te podobe, vse te osebe, ki jih z Vergilom in potem z Beatrice srečuje v svojem onstranskem imaginariju - če ne ravno iz spomina? Pa ne samo iz spomina na svojo osebno in družbeno tostransko preteklost, temveč tudi iz nekega globljega, tisočletnega spomina na celotno duhovno zgodovino človeštva. Kakor da bi se Dante znova, seveda drugače, $v$ duhu sprehajal po tistih "prostranih dvoranah spomina«, kjer »ležé zakladi neštevilnih podob«, v katerih je skoraj tisočletje pred njim Avrelij Avguštin iskal Boga (gl. X. knjigo Izpovedi: Avguštin, 1984, 202). Četudi osebno nisem konfesionalni kristjan, se vedno znova čudim in občudujem to, da je krščanstvu uspelo skozi tisočletja ohraniti v tako živem spominu pripoved o človeku, ki se je imenoval Jezus iz Nazareta, namreč ne glede na to, ali je bil ta plemeniti človek (zgolj) prerok, videc, duhovni učitelj ... ali pa je bil resnično Sin božji oziroma sam troedini Bog. Če je slednje resnica, je živa ohranitev Jezusa Kristusa v zgodovinskem spominu vse do dandanes seveda samoumevna, a tudi če je bil zgolj človek, ostaja za vse nas (ne samo za pravoverne kristjane) v živem spominu, še več, ostaja »med nami«. Njegova zadnja večerja pred križanjem se je v zahodni civilizaciji ohranila kot edini že dve tisočletji živeči antični »misterij«, kot obred obhajila, osrednji telesno-duhovni sveti »dogodek« v krščanski maši. Najbrž bi lahko kak podoben spominski most, ki sedanjost ne samo duhovno, temveč tudi telesno povezuje s tisočletno preteklostjo, našli tudi v budizmu ali kakem drugem verstvu, kljub temu pa menim (čeprav kot eden »tistih zunaj« tega ne morem zares občutiti), da je v hostiji prisotna edinstvena moč spomina, še veliko večja kot $v$ tistem kamnu, ki ga je starozavezni očak Jakob dvignil s tal, s svojega "podglavja« ter ga "postavil za spomenik«, da bi se tako on sam kot ves njegov rod večno spominjal tistega kraja in časa, kjer in ko je v sanjah uzrl lestev, ki se je vzpenjala $\mathrm{z}$ zemlje v nebo (gl. $1 \mathrm{Mz} 28,10-19)$.

Če se zdaj še malce vrnem h klasični grški filozofiji, se moram v tem eseju o spominu in duši vsaj za kratek čas ustaviti pri mojstru (v sholastiki: Mojstru) Aristotelu. Eden izmed krajših, a pomembnih in vplivnih Aristotelovih spisov, ki je bil (pozneje) vključen v zbirko Parva naturalia, je razprava Spomin in spominjanje (gr. Perí mnémes kai anamnéseos, lat. De memoria et reminiscentia). Najprej je treba reči, da se Aristotelovo razumevanje spominjanja, o katerem se analitično razpiše predvsem v drugem delu te razprave, oddalji od Platonovega in nima nič skupnega $\mathrm{z}$ orfiško eshatologijo duše. 
Pri Aristotelovem razlikovanju spomina (mnéme) in spominjanja (anámnesis) gre bolj za razliko med samim pojavom spomina in spominjanjem kot procesom, čeprav nista ostro razmejena. Ta drugi del razprave je prav po "aristotelsko« zapleten, bržkone ponekod tudi preveč, medtem ko je prvi zelo jasen in še dandanes pomemben za razumevanje spomina. $\mathrm{V}$ kontekstu pričujočega eseja bi rad posebej opozoril na tisto mesto, kjer Aristotel pravi: »Kajti vselej, ko nekdo vadi zmožnost spominjanja, mora v samem sebi reči: 'Jaz sem to že [nekoč] prej slišal (ali kako drugače zaznal)', ali pa 'Jaz sem že prej imel to misel' " (De mem., 449b23-24). Pri spomin(janj)u je torej bistveno dvoje: prvič, da zmore imeti tisti, ki se spominja, predstavno zmožnost (phantásma), $s$ katero prikliče $\mathrm{v}$ zavest predstavo o nekem ne več prisotnem predmetu ali misli (to pa nadalje implicira, da imajo spomin le »časna « bitja, ne pa bogovi, ali kvečjemu v prenesenem pomenu); in drugič, kar je za naš kontekst še bolj pomembno, Aristotel poudarja, da moram biti v svojih spominih prisoten tudi jaz sam, se pravi, vsak moj spomin mora vsebovati »subjekt«, v katerem prepoznam sebe samega. Spominjanje naj bi bilo potemtakem vselej dvojen proces, $\mathrm{v}$ katerem sta spominjajoči se in predmet spomina neločljivo povezana. (Pozneje bomo videli, da to ni tako samoumevno.) Aristotel to svojo ugotovitev podkrepi s primerom nekega Antiferona iz Oreja, ki je »trpel za duševno zmedenostjo«, kakor ljudje, ki »govorijo o lastnih fantazmah kot o svojih preteklih doživetjih, kot da bi se jih spominjali« (ibid., 541 a9 isl.). - Zanimiva je tudi Aristotelova razlaga pešanja spomina pri starejših ljudeh, če jo omenim samo mimogrede. Razlaga nam namreč, da stari ljudje pozabljamo, ker so naši možgani že "pretrdi«, da bi se vanje vtisnili spomini kakor v vosek. Po drugi strani pa naj bi bili otroški možgani še "premehki«, preveč »tekoči«, in zato si tudi otroci ne zapomnijo stvari tako dobro kot odrasli (glede tega se je Aristotel zagotovo motil). In ne nazadnje omenimo še to, da že Aristotel govori o spominskih »mestih» (gr. tópoi, lat. loci) (gl. ibid., 452a14), ki imajo pozneje ključni pomen v »umetnosti spomina« (ars memoriae).

Najslavnejši pasus o spominskih »mestih» (ali, morda bolje, »mestih spomina«) najdemo v Ciceronovi razpravi O govorniku, ki velja za temeljni kamen vse poznejše »umetnosti spomina«. Ciceron razlikuje med »naravnim« in »umetnim« spominom, ars memoriae spada seveda $\mathrm{k}$ slednjemu kot veščina krepitve spomina, ki je zelo pomembna za govornika. V 86. poglavju drugega pogovora se Ciceron naveže na dokaj morbidno anekdoto o starem pesniku in modrecu Simonidu, ki je po sesutju stropa dvorane na večerji pri skopem bogatašu Skopasu - čemur se je sam Simonid čudežno izognil s pomočjo božanskih Dvojčkov - identificiral izmaličena trupla gostov, spominjajoč se na njihova "mesta« (loci) pri omizju. Ciceron nam razlaga, da je ta tragični dogodek Simonida »vzpodbudil k odkritju, da je predvsem red tisti, ki prinese spominsko luč. Zato morajo tisti, ki želijo uriti to sposobnost, izbrati mesta in si to, kar bi radi obdržali v spominu, slikovito predstavljati v duhu in razvrstiti na ta 
mesta; tako bo urejenost mest ohranila urejenost stvari, same stvari pa bo označevala podoba stvari. Tako bomo uporabljali mesta kakor sicer vosek in podobe kakor črke« (Ciceron, 2002, 215). Gre za tehniko vizualizacije »reda" podatkov, ki sami niso nujno vizualni, ampak so npr. imena ali celo abstraktni pojmi. Ciceron v naslednjem poglavju govori o prioriteti vida pred drugimi čutili (kar je seveda platonsko, pa tudi aristotelsko in nasploh grško stališče), ko pravi, da je "najostrejše izmed vseh naših čutil [...] čutilo vida, zato lahko v duhu najlažje obdržimo zaznave, ki jih sprejmemo $\mathrm{z}$ ušesi ali z mišljenjem, če jih predamo duhu tudi s posredovanjem vida na ta način, da nevidne in presoji pogleda nedostopne stvari označuje nekakšen obris in podoba in oblika tako, da z notranjim pogledom tako rekoč zadržimo stvari, ki bi jih z mislijo lahko komajda zaobjeli« (ibid., 216).

Ob teh Ciceronovih nasvetih, kako (o)krepiti spomin, se spominjam svojih študentskih let, ko sem se učil za izpite, ki so zahtevali memoriranje velikega števila podatkov (imen, tez, povezav idr.), npr. izpit iz zgodovine filozofije: pri študiju sem si spominsko pomagal s tem, da sem si izpisoval čim bolj zgoščene povzetke študijske snovi ter jo »izrisal« v improviziranih shemah in diagramih, po možnosti na enem samem listu formata A4, ki sem ga imel potem pri izpitu "pred očmi« (seveda notranjimi) kot spominsko oporo, kot nekakšno stavbo z mnogimi sobami, od večjih dvoran do majhnih kabinetov, v katere sem »spravljal« svoje znanje. Pravzaprav je zadostovalo, da sem v takšni spominski kašči hranil le iztočnice ali »sprožilce« za svoje odgovore, nekako tako kot vrata v posamezne "prostore« znanja, med katerimi so bili tudi zelo abstraktni toposi, in te čumnate so se potem, ko sem vstopil vanje, malone samodejno odpirale, seveda pa so me pri tem vodili tudi jezik, sklepanje in asociacije. To nikakor ni bilo učenje "na pamet«, zgolj z njim gotovo ne bi mogel diplomirati na filozofiji, ampak mi je ta vizualno-predstavna »koordinatna mreža « le omogočala, da se nisem že na samem začetku poti izgubil v neskončnem labirintu pretežno abstraktnih misli. Spričo teh lastnih izkušenj sem bil še toliko bolj prijetno presenečen, ko sem mnogo pozneje v knjigi znane angleške zgodovinarke idej Frances A. Yates Umetnost spomina (The Art of Memory, 1966) bral, da ne samo Ciceron, temveč tudi drugi pomembni antični avtorji (še posebej Kvintilijan) za izboljšanje spomina priporočajo metodo vizualizacije "mest « ali »dvoran« v imaginarni palači: »Ustvarjanje loci [mest] je najbolj pomembno, kajti isti niz loci je lahko uporabljen znova in znova za spominjanje različnih gradiv« (Yates, 1994, 23). Yatesova v svoji imenitni monografiji sledi razvoju artis memorandi od antike vse do pozne renesanse, ko ta veščina kulminira - tudi pod vplivom Ramona Llulla (13. st.) in drugih sholastičnih posebnežev - v beneškem »spominskem teatru« Giulia Camilla (16. st.; o njem gl. tudi: Critchley, 2014, 19 isl.) ter v zapleteni, »magični « mnemotehniki Giordana Bruna, v njegovi razpravi O sencah idej (De umbris idearum, 1582) in njegovih drugih »hermetičnih» spisih. Brunovo 
mnemotehniko tu samo omenjam, ker je le v nekaj vrsticah ni mogoče predstaviti, kaj šele razložiti. Kljub temu pa naj namignem, da je Bruno mnemotehniko povezoval z astrologijo, saj so njegove »sence idej « zamišljene kot »zvezdne-podobe«, tj. kot odsevi platonskih idej: »Zvezdne-podobe (star-images) dejansko so 'sence idej', sence [umske] resničnosti, ki so ji bližje kot fizične sence v spodnjem svetu ...« (Yates, ibid., 213).

Renesansa, ki je bila, zlasti v quattrocentu (Alberti, Ficino, Pico idr.), veličasten in radosten spominski napor znova »oživiti« staro antično kulturo in jo harmonično povezati s krščanstvom (kljub kritikam srednjeveške sholastike, "gotike« ipd.), se v poznem cinquecentu končuje ne le v nostalgiji po davno minulih časih, ampak tudi $\mathrm{v}$ globoki melanholiji $\mathrm{v}$ odnosu do samega renesančnega "preporoda" človeka. Giordano Bruno sicer ni bil melanholik, prej nasprotno (Hipokrat bi ga bil verjetno uvrstil med sangvinike, tj. med najbolj »krvne« ali »srčne« ljudi), in najbrž je Bruno tudi zaradi svojega vročega temperamenta končal na inkvizicijski grmadi, bila pa sta globoka melanholika, vsaj sodeč po njunih delih, Brunova vélika sodobnika Montaigne in Shakespeare. Montaigne je začel pisati Eseje iz dolgoletne žalosti zaradi smrti najdražjega prijatelja Étienna, a tudi njegovi pozni eseji, na primer O ničevosti (III/9), so prežeti, še toliko bolj, z melanholijo in nostalgijo za minulimi časi, za človekovo osebno in našo skupno neponovljivo preteklostjo. Montaignu se toži po stari rimski kulturi, po »tem veličastnem in mogočnem Mestu«, med ruševinami katerega je preživel večji del svojega italijanskega potovanja (1580-1581). Njegove najljubše knjige so bila klasična dela rimskih piscev, zlasti pesnikov Vergilija, Lukrecija in Horacija ter seveda mnogih drugih njegovih (in tudi naših) neminljivih »bratov v duhu«, s katerimi se je Montaigne želel v živo pogovarjati na sprehodih v okolici svojega gradu. Ena izmed njegovih najplemenitejših in najresničnejših misli se nanaša ravno na spomin nanje: »Zaupana nam je skrb za mrtve. [...] Mrtvi so ravno tako kot moj oče, in če je on zdaj oddaljen od mene in svojega življenja osemnajst let, so oni [tj. véliki Rimljani] šestnajst stoletij; in vendar ne neham gojiti spomina nanje, z njimi se družim in prijateljujem v dovršeni in zelo živi zvezi« (Montaigne, 1999, II/9, 996; gl. tudi: Uršič, 2006, 347). - Znano je, da je Shakespeare bral in cenil Montaigna, kar lahko razberemo tudi iz njegovih dram, zlasti poznih. Njegov genialni opus je skrajni napor spomina, da v živih besedah in likih na odru za večno ohrani temne kronike angleških kraljev, opojni lesket kresne noči in Hamletovo melanholično meditacijo ob lobanji »ubogega Yoricka« ... Medtem pa na drugem koncu Evrope na oder zgodovine stopi Cervantes, ki v svojem nepresegljivem Don Kihotu ovekoveči spomin na neizbežno minule, nekdaj vélike in plemenite, ob zori novega veka pa čedalje bolj groteskne čase vitezov, oprod in mlinov na veter.

Novi vek skorajda pozabi na staro vero v nesmrtnost duše, celo takrat, ko jo racionalistično dokazuje (saj je že samo dokazovanje, ki že dolgo ne temelji več na 
takšni primarni gotovosti kot pri Sokratu, simptom te pozabe) - vse do točke, ko Kant nesmrtnost duše proglasi za zgolj spekulativno, dialektično idejo, ki pa ji mora človek kljub temu slediti, da bi ohranil svoj logos in etos. Na miselno dolgi poti od Descartesa do Kanta in naprej v moderno dobo ima v filozofiji pomembno in marsikdaj podcenjeno mesto Leibniz, ki je v Metafizični razpravi (1686) med drugim zapisal zanimivo (četudi seveda ne povsem novo) misel o spominu: »Recimo, da bi imel kakšen posameznik nenadno postati kitajski cesar, to pa pod pogojem, da pozabi na vse, kar je bil, tako kot da bi se rodil na novo. Ali bi to ne bilo dejansko, oziroma glede učinkov, ki se jih lahko zave, isto, kot če bi moral preminiti v hipu, ko bi se neki kitajski cesar rodil namesto njega? Tega pa si seveda naš posameznik nima nobenega razloga želeti« (Leibniz, 1979, 59). Torej vendarle ne: »Vse izbriši!«, ampak rajši: »Vse ohrani!«? Analogno kot za posameznega človeka bi lahko na višji oziroma splošnejši ravni rekli za neko civilizacijo v celoti, recimo za staro kitajsko ali zahodno antično: ko bi kaka naravna ali zgodovinska katastrofa, še veliko hujša od sesutja Rimskega imperija, recimo nekaj takšnega kot popolno izginotje mitične Atlantide, iz zgodovinskega spomina povsem izbrisala njeno celotno zgodovino, vse njeno znanje, vso umetnost, skratka, če bi izginil prav ves $\mathrm{v}$ tisočletjih zbrani spomin nanjo - potem ljudje moderne dobe, ki smo po Leibnizu razumna bitja, ne bi imeli nobenega razloga, da bi se imeli za potomce one pozabljene kulture, tudi če bi to dejansko bili.

Heglov nadčloveški napor "povzdigniti« (aufheben) celotno človeško zgodovino (ali vsaj vse tisto, kar naj bi bilo v njej vredno) v varstvo duha, namreč $\mathrm{z}$ »ukinitvijo« (ravno tako aufheben) njene kontingentne faktičnosti (facta bruta) v njegovi absolutni nujnosti, ki je hkrati najvišja svoboda, je bil ravno v prizadevanju, da se zgodovina oziroma zgodovinski spomin miselno "ponotranji« - pri Heglu ima namreč tudi beseda Erinnerung dvojni pomen, saj etimološko pomeni oboje, spomin(janje) in ponotranjenje - ter s tem dokončno shrani v večnosti pojmov, sekularnih potomcev nekdanjih božjih kerubov, v vseobsegajočem objemu sicer ne več svetega, vendar heglovsko gledano - nič manj popolnega, zlasti pa »konkretnega« Absoluta. Vsekakor »kapo dol«! Nisem pa povsem prepričan, ali kljub vsemu veličastju Heglovega sistema njegova filozofska razrešitev zgodovinskega spomina in nasploh "povzdignjenje» zgodovine $\mathrm{v}$ apoteozo absolutnega duha ni nekakšno danajsko darilo trpečemu človeštvu, ki se s tem še ni odrešilo dvoma v smiselnost zgodovine - obenem pa se je prav s heglovskim vstopom zgodovine $\mathrm{v}$ dvorane sámega presežno-prisotnega Absoluta, tj. z zlitjem historične faktičnosti z zgodovinsko umnostjo vesoljnega Logosa, pravzaprav res začel dogajati »konec filozofije«, njena sicer pretežno kar dobro zastrta »sámoukinitev«, ki se v našem času kaže (tudi) v tem, da se različne teoretske dejavnosti, imenovane s skupnim izrazom »filozofija «, vse bolj ukvarjajo z vsakokratno kulturo, da se ideološko mešajo v politiko, da podučujejo znanost, »kaj se pravi misliti« 
itd. Seveda je bila filozofija že od nekdaj prepletena z vsemi človeškimi dejavnostmi, vendar se morda še nikoli ni tolikanj utapljala v njih. Filozofija naj le bo - sicer drugače kot umetnost - »ogledalo časa", vendar si spodmika svoj raison d'être, svoje primarno poslanstvo, če pozablja, da je kot ljubezen do modrosti predvsem varuhinja »večnih vprašanj«, philosophia perennis.

Malce se moram(o) odpočiti od teh silnih filozofskih abstrakcij, zato se na našem sprehodu, pri premišljevanju o spominu in celovitosti duše, za nekaj dragocenih trenutkov ustavimo pri Marcelu Proustu in njegovem Iskanju izgubljenega časa iskanju v spominu, seveda, le kje drugje, vendar ne samo v spominu kot priklicu neke minule podobe, dogodka ali misli, temveč v "posedanjenem « spominu, v spominu, ki se iz preteklosti prav zares preseli $\mathrm{v}$ živo sedanjost. Kajti ravno $\mathrm{v}$ tej spominski »magiji«, ki se dogaja s pomočjo literature, pravzaprav $v$ njej, vendar ne samo v njej, Proust najde svoj »izgubljeni čas«. Najbolj znan primer »posedanjenja preteklosti« je odlomek o magdalenicah iz prve knjige, $V$ Swannovem svetu, vendar si tu rajši prikličimo v spomin odlomek iz zadnje, sedme knjige Proustovega vélikega cikla s povednim naslovom Spet najdeni čas. Prvoosebni pripovedovalec (recimo mu kar Proust) doživi trenutek "posedanjene preteklosti«, ko se pri vhodu v pariško palačo kneginje Guermantske, kamor hiti na sprejem, spotakne ob stopnico: neroden gib takrat sproži v njem plaz spominov, ki pred njegovimi notranjimi očmi pričarajo Benetke, natanko takšne, kot jih je videl in doživljal pred mnogimi leti: »V trenutku, ko sem spet ujel ravnotežje in položil nogo na kamen, ki je bil malo nižji od prejšnjega [...] se me je spet rahlo dotaknil tisti nerazločni, slepeče svetli privid, kakor da bi mi hotel reči: 'Ujemi me v letu, če imaš še toliko moči, in poskusi rešiti uganko sreče, ki ti jo zastavljam!' In takoj sem ga prepoznal: bile so Benetke, o katerih mi vsi moji napori, da bi jih opisal, in vse trenutne slike, ki naj bi jih nekdaj posnel moj spomin, niso nikoli povedali nič, zdaj pa mi jih je vrnil občutek, ki sem ga zaznal nekoč na dveh neenakih ploščah tlaka v krstilnici Svetega Marka, in ta mi je vrnil tudi vse druge, tistega dne z njim povezane občutke, ki so dotlej čakali na svojem mestu v vrsti pozabljenih dni, od koder jih je z neustavljivo silo potegnilo neko nepričakovano naključje« (Proust, 1997, 180-182). V nadaljevanju pa še nekoliko bolj na splošno, malone »teoretsko« opisuje takšna spominska doživetja: »In glej, nenadoma se je zgodilo, da strogi zakon ni več učinkoval, da ga je začasno razveljavila čudovita umetnija narave, ki je povzročila, da se je neki občutek - žvenk žličke ob krožnik, enak naslov knjige itd. zableščal v preteklosti, kjer ga je lahko okusila moja domišljija, in hkrati v sedanjosti, kjer je stvarna vznemirjenost mojih čutov zaradi žvenketa, dotika platna itd. dodala sanjarijam domišljije še nekaj, kar jim navadno manjka, se pravi pojem obstajanja, in je s to zvijačo mojemu bitju omogočila, da je - samo za tren - ujelo, osamilo in zaustavilo tisto, česar ne more nikoli zgrabiti: malo časa v čisti obliki« (ibid., 186-187). - Je v 
tem drobcu ustavljenega časa tista "večnost trenutka«, ki jo iščejo mistiki? Večnost, ki ne potrebuje niti (individualne) nesmrtnosti niti neskončnega raztezanja časa $\mathrm{v}$ preteklost in prihodnost (ter s tem niti spomina niti pričakovanja), saj je »vselej in nikoli«, namreč vselej »tu in zdaj«, čeprav nikoli v drsečem času profane »realnosti«, ampak je v »četrtem «, presežnem času, ki pravzaprav ni več čas, temveč večnost sáma » čisti obliki«? Saj samo to »kratko večnost «, ki ne traja, ampak preprosto je, lahko skusi človeška duša, neskončne večnosti ne more, vsaj »tu« ne. Toda koliko poti mora človek prehoditi, da pride do enega samega trenutka svoje preproste, »kratke večnosti«! A še potem ko se »vrne« iz nje v minljivi svet, si mora zagotoviti kak »spominek«, da je ne bi pozabil (tako kot Pascal ali očak Jakob), da bi mu tisti trenutek vse preostalo življenje dajal upanje in pogum, seveda tudi vero - saj lahko duša brez nje kmalu zatava $\mathrm{v} » \mathrm{mračnem} \mathrm{gozdu}$ « (mi ritrovai per una selva oscura ...).

V sodobni oziroma novejši analitični filozofiji (v najširšem pomenu te oznake) so razprave o spominu, zelo splošno rečeno, naslednice tozadevne Aristotelove tematike in tudi njegovega razumskega načina razmišljanja de memoria et reminiscentia. Znanstveno in filozofsko raziskovanje spomina in pozabe se dandanes razvija predvsem v okviru kognitivne filozofije in/ali znanosti, zlasti nevrologije, psihologije in informatike. $\mathrm{V}$ akademskih krogih in strokovni literaturi obstaja o spominu množica raznih hipotez, tez in teorij, ki tako ali drugače razlagajo psihične spominske fenomene v odnosu do njihovih (domnevnih, ne še povsem pojasnjenih) možganskih korelatov. Tu seveda ne nameravam in zaradi formata tega spisa niti ne morem vstopiti $\mathrm{v}$ ta teoretski labirint, kljub temu pa se želim na kratko ustaviti pri nekem zanimivem »detajlu«, presenetljivi hipotezi pred nekaj leti umrlega analitičnega filozofa Dereka Parfita o »kvazispominih« (quasi-memories). Spomnimo se najprej, da Aristotel v svoji razpravi ugotavlja, da je spominjanje dvojen proces, ki povezuje predstavno zmožnost priklica nekega ne več zaznavno prisotnega predmeta ali misli ter zavestno gotovost, da sem prav jaz sam tisti, ki sem tisto, česar se spominjam, v lastni preteklosti izkusil ali (že takrat) mislil. Drugače rečeno, da se tega-in-tega spominja(m kot) oseba. Parfit pa v svojem glavnem delu Razlogi in osebe (Reasons and Persons, 1984), kjer obširno in poglobljeno razpravlja o filozofskem problemu osebne identitete, podvomi ravno o tem, da so človeški spomini mogoči zgolj kot osebni spomini (pri čemer pa nima $\mathrm{v}$ mislih kakega kolektivnega ali zgodovinskega spomina). Ko piše o obstoju človekovih (mojih ali tvojih ali njenih ali njegovih) »drugih jazov«, Parfit izrazi zanimivo idejo, da »bi bilo možno razmišljati o izkustvih na povsem 'neoseben' način « (Parfit, 1984, 55; gl. tudi: Bernecker v Nikulin, 2015, 312-315). Ta misel postane še posebno nenavadna, če jo apliciramo na spominska izkustva, tj. na priklic preteklih doživetij, ki smo jih shranili v spominu, na primer pogovor $\mathrm{z}$ neko osebo, recimo z gospodom M. pred enim mesecem. Ob tem se postavlja vprašanje, ali je moj spomin na takratni 
pogovor z M. prenosljiv kot spomin $\mathrm{v}$ zavest neke druge osebe, ki se z M. sploh ni nikoli pogovarjala. Splošno rečeno, ali obstajajo »neosebni« spomini? Ta misel se nam prvi hip zdi absurdna, tako kot že staremu mojstru Aristotelu, skregana z zdravo pametjo. Vendar Parfit ne izključuje možnosti, da bi se lahko spominjali tudi izkustev drugih jazov, še več, drugih oseb - in za takšno možnost uvede izraz »kvazispomini«. Jaz se »kvazispominjam« nekega preteklega izkustva, ki ga je nekdo (kak moj »drugi jaz«) izkusil, pri čemer doživljam ta spomin kot povezan z mojim preteklim izkustvom. (Gl. tudi: Bernecker, 2010, 51-61.) »Kvazispomini« nas spomnijo na znan, a vsakokrat znova osupljiv fenomen déjà $v u$, o katerem pa Parfit, vsaj v tej knjigi, ne govori. Osebno menim, da je razlika med »kvazispomini«, kot jih opredeli Parfit, in pojavom déjà vu v tem, da slednjega razum ravno ne more sprejeti kot lasten spomin, saj je neka situacija, ki se nam kaže kot »že videna«, do najmanjše podrobnosti enaka s sedanjo, kar pa je praktično nemogoče.

Parfitova hipoteza je gotovo zanimiva, vendar ostaja vprašanje, le kako naj vem, da je moj »kvazispomin« res povezan s spominskim izkustvom nekoga drugega. Kakorkoli že, pa nam »tuji« spomini, ne glede na to, ali so izkustveno vezani na druge osebe ali ne, niso nekaj povsem tujega. Na primer, spominjam se neke mestne vedute v Benetkah (recimo, lepega trga pri cerkvi San Stefano), ko mi po mnogih letih znova pride $\mathrm{v}$ roke fotografija tega trga; zanjo vem, da sem jo sam posnel, toda kljub temu je mogoče (še več, običajno je res tako), da ne morem v svojem živem spominu »videti« oziroma »prepoznati« sebe na tem trgu (ne na sliki, ampak »za kamero«), namreč sebe $\mathrm{v}$ tistem minulem času, ko sem posnel to fotografijo (najbrž bi bilo to lažje $\mathrm{z}$ nizom fotografij, tako kot pri moji Islandiji) - in od tod je samo še korak do bizarnega, čeprav povsem racionalnega vprašanja: Kaj pa, če je to fotografijo posnel kdo drug? Še več: Kaj pa, če se s to sliko spominjam spominov nekega »drugega jaza « ali celo neke druge osebe? Kajti misel, da bi človek vendarle lahko imel »kvazispomine« v emfatičnem pomenu, se porodi ob razumsko povsem sprejemljivem spoznanju, da v enem samem življenju, od rojstva do smrti, živi in mineva v meni, v vseh nas, množica različnih jazov - in da jih povezuje ravno moč spomina, čeprav je pomanjkljiva in pogosto varljiva. Kljub temu, da sem se v tem življenju že večkrat prerodil kot ptič feniks in da moji vsakokrat novi jazi, "nova življenja» naseljujejo to starajoče se telo, se živo spominjam vsaj nekaterih doživetij iz otroštva in mladosti, torej doživetij nekih mojih že davno minulih jazov, za katere bi morda lahko celo rekel, da jih je doživela neka druga, zdaj mi že skoraj tuja oseba. Kako pa je s spominom in celovitostjo moje duše? Mar je s tem izgubljena? Ne povsem. Parfit bi nemara rekel, da je celo na novo, na višji ravni pridobljena. (Sicer pa ste gotovo že opazili, da bi bilo treba v tej razpravi jasneje razmejiti oziroma definirati pojma 'jaz' in 'oseba', a naj to ostane naloga za kdaj drugič.) In če obstajajo »kvazispomini« - se bolj daljnosežno od mene sprašuje Parfit - zakaj 
se potemtakem ne bi spominjal tudi doživetij tistih drugih jazov, ki so živeli in umrli že pred mojim rojstvom? Morda pa je prav v tem spoznanju razrešitev stare uganke o preseljevanju duš? »Mnogokrat sem bil rojen, o Arjuna, / in mnogokrat si bil rojen ti - / a jaz se spominjam preteklih življenj, / pozabil si ti tiste dni« ... Tudi Parfit se navezuje na indijsko filozofijo, zlasti na budizem, in poudarja, da imajo »kvazispomini « ter nasploh naša "neosebna « izkustva tudi etični pomen: »Če prenehamo verjeti, da so naše osebe ločeno obstoječe entitete [...] potem nam je bolj pomembna kvaliteta izkustev, kot to, čigava izkustva so «(Parfit, 1984, 346). Seveda so tisti filozofi, ki jim je bližji personalizem (v najširšem pomenu), kritizirali takšno stališče do osebe. (Nekaj več o pojmovanju osebe in »drugih jazov« pri Parfitu gl. tudi v: Uršič, 2002, 113-124.)

Digitalni spomin, ki je poleg procesiranja bitov jedro sodobnih računalnikov, postopoma, korak za korakom, malone neopazno, vendar toliko bolj vztrajno izpodriva živi človekov spomin. $\mathrm{V}$ digitalnem spominu je mogoče $\mathrm{z}$ binarno kodo zapisati prav vse, od Beethovnove Devete simfonije do žaljivke na tviterju. Elektroni so »nevtralni« v odnosu do človeških čustev in strasti. V marsičem je ta nevtralnost "mislečih strojev« seveda dobra: računalnik je v osnovi tabula rasa, na katero lahko človek zapisuje svoje misli ter "mu « daje naloge, ki jih sam v tem neznansko zapletenem svetu ne bi znal (več) reševati. Brez računalnikov ne bi znali več živeti, ali vsaj zelo težko. V novem stoletju smo se že tako navadili nanje in na sobivanje z njimi, kakor so se v prejšnjem naši starši navadili na elektriko, avtomobile in antibiotike. A kljub velikanskim koristim, ki jih imamo od računalnikov in interneta, ne smemo pozabiti, da je digitalni spomin (vsaj za zdaj) mrtev spomin. Vse neznansko velike baze podatkov nam prav nič ne pomagajo, če podatkov, ki jih prikličemo iz njih, ne razumemo, če jih ne znamo miselno povezovati v širše in globlje celote. Skratka, če jim ne vdihne smisla živa duša, živi duh. Najbrž se bo kak sodobni »digitalni optimist « (ali tehnološki »realist «) ob tej moji »staroveškosti« prizanesljivo nasmehnil in pametno pripomnil, da nam ravno računalniki in informacijska omrežja vse bolj pomagajo povezovati podatke v širše, "globalne « celote (na primer, Wikipedia), vendar to drži bolj na površinski ravni, kajti sama »banka podatkov«, če je še tako velika in dobro urejena, nam še ne omogoča razumevanja njihove smiselne »globine«. Poleg tega pa informacijska omrežja še zdaleč niso tako nevtralna, kot je sam računalniški hardver (a tudi o nevtralnosti slednjega bi se dalo razpravljati), kajti »za« omrežji ali spletnimi "portali« ali "platformami« se vselej skrivajo neki subjekti, individualni ali korporacijski. Za večino informacijskih omrežij na današnji World Wide Web se skriva denar, kapital, posvetna moč. Ne prav za vsemi, za večino pa. Seveda na svetu ni nič idealnega, tudi v preteklosti je za največjimi umetninami človeštva, na primer za Michelangelovim Davidom, stal (takrat medičejski) denar, vendar je dandanes nov problem v tem, da so za večino 
nas, lahkovernih oziroma lahkomiselnih uporabnikov interneta, interesi njihovih subjektov »v ozadju « večinoma zastrti, saj je ravno v tej zastrtosti eden izmed glavnih pogojev učinkovitosti teh mrež. Ni še sicer tako hudo kot v distopičnem filmu Matrica in najbrž prihodnost nikoli ne bo ravno takšna, kot je prikazana v tem filmu, kar pa ne pomeni, da ne bo na "podobno drugačen« način huda. Dobri znanstvenofantastični filmi so »kvazispomini« na prihodnost.

A vrnimo se k vprašanju spomina in celovitosti duše: digitalni spomin ni »le« mrtev, kajti mrtvo bitje je tisto, ki je bilo nekoč živo, ampak je preprosto neživ, tako kot kamen ali lokomotiva. Ja, tudi knjiga je sama po sebi neživa, »oživimo« jo šele z branjem, razumevanjem in občutenjem tega, kar v njej piše. Toda zakaj nam knjiga vendarle pomeni nekakšen fetiš (v pozitivnem smislu), medtem ko tega ne moremo reči za USB-ključek ali digitalno disketo? S knjigo »hodimo spat «, vsaj naša starejša generacija, medtem ko mlajšim in najmlajšim postaja fetiš (v malone malikovalskem pomenu) »pametni« telefon ali tablica. Ampak v čem je pravzaprav razlika? Saj tudi z enim samim iztrganim listom iz knjige ne hodimo spat, kakor mladi ne $z$ eno samo iz omrežja ločeno digitalno datoteko? Mar potemtakem bistvene razlike med analognim spominom, zapisanim $\mathrm{v}$ knjigi, in digitalnim, zapisanem na spominski ploščici digitalne »igračke«, vendarle ni? Seveda gre življenje naprej, tehnologija se razvija ... pa vendar stvari niso tako enostavne. $Z$ »mislečimi stroji« - ne glede na to, kako si predstavljamo "njihovo« mišljenje - se je dejansko začelo novo obdobje v človeški civilizaciji in posledice odkritja računalnikov so že in bodo sčasoma še bolj vidne in odločilne, tako v dobrem kakor tudi, žal, v slabem smislu. Nekateri digitalni optimisti se zavzemajo za to, naj se naše misli in računalniške datoteke čim prej in čim bolj tesno prepletejo, češ da se bomo le tako izognili nevarnosti, da bi nas računalniki evolucijsko prehiteli. Rečeno v prispodobi - ki pa ni več zgolj prispodoba -, svetujejo nam, naj se skupaj $\mathrm{z}$ »umetnimi inteligencami« (pravzaprav $v$ njih) dvignemo v digitalne »oblake«. Osebno nisem ravno prepričan niti v dóbrost niti $\mathrm{v}$ evolucijsko uspešnost strategije našega stapljanja $\mathrm{z}$ »umetno inteligenco « - ali, če uporabim izraz, ki se zadnje čase vse bolj uveljavlja, $\mathrm{z} »$ umetnimi duhovi« (artificial minds). Je duh sploh lahko umeten?

Eden izmed pionirjev začetne faze digitalizacije sveta $\mathrm{v}$ 80-ih letih minulega stoletja, Jaron Lanier, je leta 2010 na internetu objavil zelo kritično knjigo Ti nisi igračka (You Are Not a Gadget), namreč digitalna igračka (sicer ima angl. beseda gadget širši pomen: 'majhno orodje', 'pripravica'), z udarnim podnaslovom »Manifest«. V tej knjigi izhaja iz prepričanja, da se je »najbolj pomembno vprašati, kako neka tehnologija spreminja ljudi« (Lanier, 2010, 27). Digitalna tehnologija nas namreč, hočeš nočeš, zelo spreminja, počasi in vztrajno nam »leze pod kožo - in prav ta njena zastrta nevarnost, ki je v svojem rutinskem vsakdanu niti ne opazimo, se je večinoma ne zavedamo, je morda celo hujša od neposredne nevarnosti, recimo, jedrske tehnologije, ki jo vendarle 
nekako uspevamo obvladovati, čeprav je že zarezala nekaj strašnih ran v naš človeški svet. Za digitalno tehnologijo lahko rečemo, da je njena lastna oziroma inherentna nevarnost, vsaj za zdaj, bolj "notranja « kot zunanja. Lanier ugotavlja, da je eden izmed najbolj zaskrbljujočih vidikov te nevarnosti »fragmentiranje« tako posamezne človeške osebe kot celotne človeške družbe in kulture - kljub deklariranemu namenu večine (vsaj legalnih) spletnih omrežij in navsezadnje tudi interneta kot takega, da izboljšujejo pretok informacij in komunikacijo med ljudmi, da globalno povezujejo človeštvo itd. Navajam malce daljši, zelo poveden odlomek iz poglavja Lanierjeve knjige »Fragmenti niso ljudje«: »Nekaj je začelo iti narobe z digitalno revolucijo na začetku 21. stoletja. Hudournik nepomembnih zapisov je začel preplavljati internet, ki ga včasih imenujemo Splet 2.0. Ta ideologija promovira na površini spleta radikalno svobodo, toda ta svoboda je, ironično, namenjena bolj strojem kot ljudem. Kljub temu se včasih proglaša za 'odprto kulturo'. Anonimni komentarji na blogih, puhla video besedičenja, lahkotne mešanice vsega mogočega se zdijo trivialne in neškodljive, toda ta vsepovsod razširjena praksa fragmentarne komunikacije je, vzeta v celoti, degradirala medosebno sodelovanje. Zdaj se komunikacijo pogosto izkusi kot nekakšen nadčloveški fenomen, ki je dvignjen nad posameznike. Nova generacija odrašča z zmanjšanimi pričakovanji, kaj [neka] oseba lahko je in kaj lahko iz sebe razvije« (Lanier, 2010, 6).

Kljub tem tesnobnim mislim in slutnjam, ki nas v našem »krasnem novem svetu « ob somraku bogov obletavajo v duhu kakor demoni na Goyevi grafiki Sen razuma poraja pošasti, pa želim ta esej končati bolj optimistično: kot se je stari Odisej po vseh zgodah in nezgodah vrnil domov na Itako in kot se njegov moderni dvojnik v slavnem Kubrickovem filmu Odiseja 2001 vrača kot »Zvezdno dete« iz vseh tistih fantastično tujih svetov »onstran neskončnosti« nazaj k svoji materi Zemlji, pri čemer ga vodi neznana, skrivnostna, a nedvomno za človeka dobra in v odločilnih trenutkih prisotna presežna Moč (v samem filmu črni »Monolit«), tako naj tudi nas, na pragu tretjega tisočletja, tu in zdaj in vselej, spomin vrača k tistemu, česar ne smemo pozabiti, saj je najdragocenejše, kar imamo - $d u \check{s} a$.

\section{Bibliografija}

Alighieri, Dante, Božanska komedija, Ljubljana 1994.

Aristotle, De memoria et reminiscentia, v: The Works of Aristotle, I. del: Parva naturalia, Oxford 1908.

Avguštin, Avrelij, Izpovedi, Celje 1984.

Bernecker, S., Memory: A Philosophical Study, Oxford 2010.

Blake, W., Poroka Pekla in Nebes, Problemi - Literatura, X, 1972, »Erotična« št. 111112 , str. $13-20$. 
Cassirer, E., Mythical Thought (The Philosophy of Symbolic Forms, 1-2), New Haven 1955.

Chateaubriand, F. R. de, Spomini z onkraj groba, Ljubljana 1989.

Ciceron, Mark Tulij, O govorniku, Ljubljana 2002.

Critchley, S., Memory Theatre, New York 2014.

Dickinson, E., The Complete Poems, New York 1961.

Dummett, M., Truth and Other Enigmas, London 1978.

Eliade, M., Zgodovina religioznih verovanj in idej, Ljubljana 1996.

Fragmenti predsokratikov (zv. I-III), Ljubljana 2012.

Herodot, Zgodbe, Ljubljana 1953.

Homer, Iliada in Odiseja, Ljubljana 1951.

Lanier, J., You Are Not a Gadget: A Manifesto, New York 2010.

Leibniz, G. W., Izbrani filozofski spisi, Ljubljana 1979.

Montaigne, M. de, Les Essais (I-III), Pariz 1999.

Nikulin, D. (ur.), Memory: A History, Oxford 2015.

Parfit, D., Reasons and Persons, Oxford 1984.

Pascal, B., Misli, Celje 1980.

Platon, Zbrana dela, Celje 2004.

Plotin, Zbrani spisi (II. zv.), Ljubljana 2018.

Proust, M., Spet najdeni čas (Iskanje izgubljenega časa, VII. knjiga), Ljubljana 1997.

Uršič, M., Razpoke, Ljubljana 1985.

Uršič, M., Štirje časi - Pomlad, Ljubljana 2002.

Uršič, M., Sedmerke (Štirje časi - Poletje, II. del), Ljubljana 2006.

Uršič, M., O sencah (Štirje časi - Zima), Ljubljana 2015.

Yates, F. A., The Art of Memory, London 1994. 


\section{Marko Uršič}

\section{O spominu in celovitosti duše}

Ključne besede: spomin, anámnesis, preseljevanje duš, kvazispomini, digitalni spomin, Platon, Aristotel, Ciceron, Plotin, Dante, François-René de Chateaubriand, Parfit, Marcel Proust

Avtor izhaja iz platonskega prepričanja, da je spominjanje (anámnesis) bistveno za sámospoznanje, namreč kot možnost presežne celovitosti duše. Ob prepletanju esejistično ubesedenih osebnih spominskih izkustev in teoretsko filozofskih premislekov je v središču pozornosti odnos med spominskimi »predmeti« oziroma predstavami in subjektom, tj. osebo, ki se spominja. V osrednjem delu članka avtor naniza nekaj ključnih spominskih »aporij«, ki segajo od starega Egipta in Grčije do moderne dobe, od klasične mnemotehnike do hipotetičnih »kvazispominov« ter do sodobnega digitalnega spomina, ki vse bolj izpodriva živo človeško spominjanje. Kljub temu pa avtor izraža upanje, da duša tudi dandanes zmore s spominskim »iskanjem izgubljenega časa« ohranjati svojo celovitost - kot živi duh, kot oseba. 


\section{Marko Uršič}

\section{On Memory and the Unity of Soul}

Keywords: memory, anámnesis, transmigration of souls, quasi-memories, digital memory; Plato, Aristotle, Cicero, Plotinus, Dante, François-René de Chateaubriand, Parfit, Marcel Proust.

The author's starting point is the Platonic belief that memory as reminiscence (anámnesis) is essential for self-knowledge, for the possibility of the transcendent unity of the soul. By intertwining historical philosophical considerations of memory with some personal experiences, there is in a focus on the relation between "objects" of memories and their subject, i.e. the person who remembers. In the central part of this article, some main aporías of memory are presented and discussed, extending from ancient Egypt and Greece to modern times, from classical mnemotechnics to the hypothetical "quasi-memories" in modern cognitive philosophy, and finally to the contemporary digital memory, which persistently supersedes the live human faculty of memory. Nevertheless, the author expresses his hope that the human soul, in her "search of lost time", is still able to preserve her essential unity - as a living spirit, as a person. 